\title{
MCM7 wt Allele
}

National Cancer Institute

\section{Source}

National Cancer Institute. MCM7 wt Allele. NCI Thesaurus. Code C52308.

Human MCM7 wild-type allele is located within 7q21.3-q22.1 and is approximately $9 \mathrm{~kb}$ in length. This allele, which encodes DNA replication licensing factor MCM7 protein, plays a role in the mediation of chromosomal duplication. 